\title{
How does network governance affect social-ecological fit across the land- sea interface? An empirical assessment from the Lesser Antilles
}

\author{
Jeremy Pittman $^{1}$ and Derek Armitage ${ }^{2}$
}

\begin{abstract}
Governance across the land-sea interface presents many challenges related to (1) the engagement of diverse actors and systems of knowledge, (2) the coordinated management of shared ecological resources, and (3) the development of mechanisms to address or account for biogeochemical (e.g., nutrient flows) and ecological (e.g., species movements) interdependencies between marine and terrestrial systems. If left unaddressed, these challenges can lead to multiple problems of social-ecological fit stemming from governance fragmentation or inattention to various components of land-sea systems. Network governance is hypothesized to address these multiple challenges, yet its specific role in affecting social-ecological fit across the land-sea interface is not well understood. We aim to improve this understanding by examining how network governance affects social-ecological fit across the land-sea interface in two empirical case studies from the Lesser Antilles: Dominica and Saint Lucia. We found that network governance plays a clear role in coordinating management of shared resources and providing capacity to address interactions between ecological entities. Yet, its potential role in engaging diverse actors and addressing, specifically, biogeochemical interactions across the land-sea interface has not been fully realized. Our research suggests that network governance is beneficial, but not sufficient, to improve social-ecological fit across the land-sea interface. Strategically leveraging the network processes (e.g., triadic closure) leading to the existing governance networks could prove useful in addressing the current deficiencies in the networks. Additionally, the interplay between hierarchical and networked modes of governance appears to be a critical issue in determining social-ecological fit at the land-sea interface.
\end{abstract}

Key Words: land-sea interface; multilevel exponential random graphs; network governance; social-ecological fit; social-ecological networks

\section{INTRODUCTION}

Network governance is thought to enhance our capacity to address sustainability problems in social-ecological systems (SESs) (Voß et al. 2007, Ansell and Gash 2008, Klijn and Koppenjan 2012, Bixler et al. 2016). Network governance is characterized by a shift in reliance away from top-down or hierarchical modes of decision-making to more decentralized, self-organizing modes of governance (Newig et al. 2010). The networked mode typically involves collaboration between different governance actors, and as such, it is theorized to improve participation and legitimacy (Ernoul and Wardell-Johnson 2013, Sandström et al. 2014), increase integration and application of diverse knowledge sources (Armitage et al. 2009, Newig et al. 2010), better leverage the distinct capacities of different actors by supporting collaboration and collective action (Engle and Lemos 2010), enhance the responsiveness of governance to emerging social and ecological problems (Duit and Galaz 2008, Duit et al. 2010), and improve the fit between governance and ecological systems (Guerrero et al. 2015a).

Achieving such a fit is a pervasive challenge in the Lesser Antilles islands of the Caribbean (Saffache and Angelelli 2010, Sweeney and Corbin 2011, Pittman et al. 2015, Walters 2016). By drawing on network governance theory and the concept of socialecological fit, we aim to examine the following research question: How does the self-organization of governance actors influence social-ecological fit across the land-sea interface? Our goals are to (1) characterize how different, self-organizing governance networks contribute to capacity for governing across the landsea interface, and (2) identify strategies for improving governance in this regard. Our research is focused on two comparative case studies from Dominica and Saint Lucia. Each of these cases provides a distinct context for exploring the value of network governance to improve social-ecological fit across the land-sea interface.

Current research aims to examine how and when governance network arrangements lead to particular and desired outcomes, such as better coordination between multiple actors and the ability to address issues of scale (Bergsten et al. 2014, Bodin et al. 2014, Guerrero et al. 2015a, Kininmonth et al. 2015). The concept of social-ecological fit has emerged as a useful lens in this regard (Bodin et al. 2014, Epstein et al. 2015). Social-ecological fit, drawing on earlier conceptions of institutional fit (Young 2002), refers to the degree of alignment or match between governance systems and various dimensions of the SES in which governance is embedded (Folke et al. 2007, Epstein et al. 2015).

Much early work on fit focused on the coherence between institutions as the main elements of governance systems and SES dimensions (e.g., Ekstrom and Young 2009). Galaz et al. (2008) first called for a broader account of governance in analyses of fit, and proposed several governance system components beyond institutions considered important for fit - including patterns of interactions or networks between different governance actors. Subsequently, Bodin et al. (2014) provided the theoretical and methodological foundations to examine how patterns of interactions in networks affect social-ecological fit, and Guerrero et al. (2015a) recently extended this approach to understand fit in network governance. The focus on network governance provides an entry point to consider networks and institutions simultaneously, as network governance theory highlights the interplay between these two elements of governance systems (Klijn and Koppenjan 2012).

${ }^{1}$ Environmental Change and Governance Group, School of Planning, University of Waterloo, ${ }^{2}$ Environmental Change and Governance Group, School of Environment, Resources and Sustainability, University of Waterloo 
There are also multiple types of fit found in the literature, which are often distinguished by the SES features of interest, and some commonly employed types of fit include spatial, functional, and temporal (Table 1). However, a focus on single features or a subset of features can be problematic, especially if the intent is to optimize governance for certain features without considering others (Folke et al. 2007, Epstein et al. 2015). Hence, socialecological fit typically encompasses multiple types of fit simultaneously, and analyses of social-ecological fit are focused on the specific governance challenges that lead to a plethora of fit problems (Rijke et al. 2012, 2013, Bodin et al. 2014, Guerrero et al. 2015a). Social-ecological fit is a means of characterizing capacities to deal with such problems.

Table 1. Types of misfit in social-ecological systems from the literature.

\begin{tabular}{ll}
\hline \hline Type & Description \\
\hline Spatial & $\begin{array}{l}\text { Institutional jurisdictions do not match areal } \\
\text { extent of a resource, its users, or the impacts } \\
\text { associated with resource use. }\end{array}$
\end{tabular}

Temporal Institutional creation is either too soon or too late in relation to a certain problem or ecosystem process. Decision-making processes, as structured by institutions, are not able to produce timely decisions in relation to a problem.

Functional Institutional scope does not adequately account for functional diversity and variety in a socialecological system.

Cascading Institutions are unable to buffer negative effects effects and feedbacks sufficiently to prevent their propagation throughout a social-ecological system.

Threshold Institutions are unable to recognize looming behavior thresholds and avoid abrupt ecological shifts. Institutions are unable to effectively manage extremes and variability in the system.

Sources: Young 2002, Folke et al. 2007, Galaz et al. 2008

Social-ecological misfit leads to a number of particularly acute governance challenges across the land-sea interface. Pittman and Armitage (2016), in a recent systematic review, highlighted three main governance challenges in this context: (1) engaging diverse actors to access multiple forms of knowledge, (2) coordinating management of ecological resources across social boundaries, and (3) undertaking governance at scales that are relevant to biogeochemical and ecological interactions. These challenges are all founded in social-ecological misfit. They do not represent all issues of potential interest in an examination of social-ecological fit (e.g., social justice), but they represent an adequate subset of issues with importance to governing land-sea interactions. For example, fragmentation between governance systems focused on the land and those on the sea can lead to decisions about land use that do not include all relevant actors and ignore potential implications for coastal communities and ecosystems, such as sedimentation, eutrophication, and subsequent impacts to the resources on which coastal communities depend (Glavovic et al. 2015, Norström et al. 2016). Detrimental land use, aside from producing general issues with sedimentation and eutrophication, can also place coastal communities and ecosystems at greater risk from storms and extreme precipitation events, which amplify the physical processes driving erosion, sedimentation, and nutrient transport (Álvarez-Romero et al. 2011). These examples highlight the importance of engaging diverse actors, coordinating management, and undertaking governance at appropriate scales in land-sea systems.

\section{METHODS}

\section{Case studies and data collection}

The southwest coast of Dominica and the southeast coast of Saint Lucia provide useful case studies of governance across the landsea interface (Fig. 1). Each case study region was chosen in consultation with partners from each island, and each region contains multiple catchments and administrative divisions. The case studies have key socioeconomic and ecological similarities yet different approaches to governance. Both exhibit selforganizing governance networks to various degrees. However, governance in the Saint Lucian case is more top-down and has involved different strategies (e.g., ratification of the Land-base Sources of Pollution Protocol-a relevant multilateral agreement), whereas the approach in the Dominican case is more bottom-up and not guided as directly by international commitments. We should note that the Saint Lucian case also exhibits a different governance context than other areas of the island, and the same can be said for the Dominican case. The Saint Lucian case demonstrates the role of self-organizing governance networks in a subnational region with less experience in participatory governance than other parts of the island (i.e., there is much more experience in the Soufriere Marine Management Area) (see Pittman et al. 2015), and the Dominican case demonstrates the role of such governance networks in a subnational region with arguably more participatory governance experience than other parts of the island (i.e., the Soufriere-Scott's Head Marine Reserve's multistakeholder management committee

Fig. 1. Map of region and focal islands. The red areas represent the case studies.

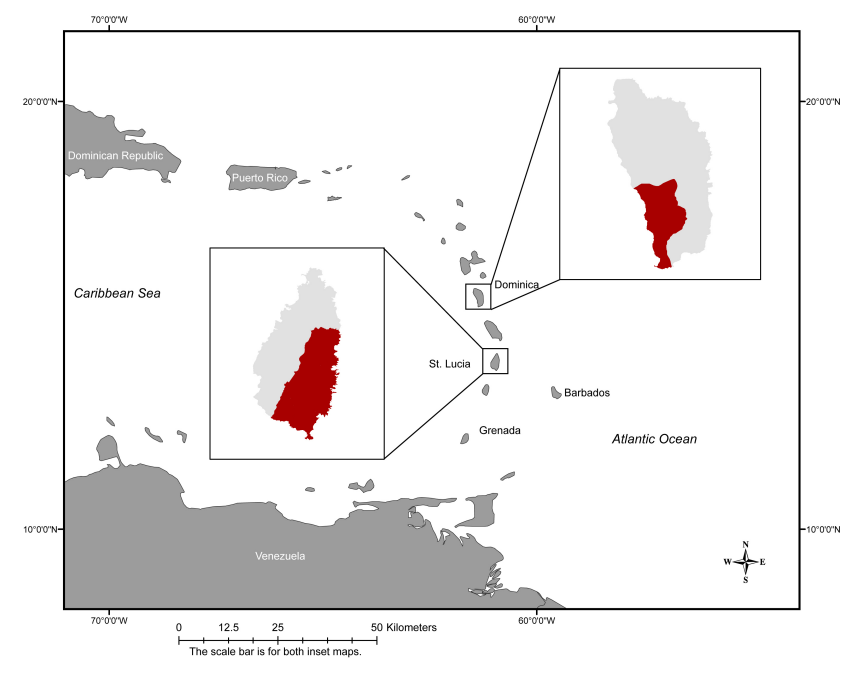


is included in the case). These distinctions between cases help provide breadth in terms of the multilevel interactions between community and national governance networks, institutions, and priorities. Population and population densities are also important distinctions between these two contexts. Saint Lucia has a higher population and is much more densely populated than Dominica, which allows us to compare across various levels of resource use and intensity.

Qualitative and quantitative data on governance networks and land-sea interactions were gathered using interviews with representatives from relevant governance organizations (e.g., government agencies, nongovernmental organizations) (Table 2) (Borrás and Olsen 2007). An initial contact list of relevant organizations was constructed by examining participation in key regional and international meetings (e.g., Global Programme of Action for the Protection of the Marine Environment from Landbased Activities). Partnerships were then formed with lead organizations in each context, and representatives from these organizations helped develop a complete list of contacts for organizations that were relevant for governing land-sea interactions. Additional organizations were added if they were mentioned as relevant by at least two interview participants. Twenty-eight of the 35 relevant organizations in the Saint Lucia case were interviewed, while 36 of the 47 relevant organizations in the Dominica case were interviewed (Table 2). The research instrument contained a mix of structured and semistructured components, which allowed for focused data gathering regarding governance networks and land-sea interactions but also for the exploration of emergent themes. Quantitative governance network information was gathered by asking participants with whom they collaborate or coordinate regarding issues arising from land-sea interactions. Qualitative information was gathered by asking respondents open-ended questions about the drivers of challenges arising from land-sea interactions, institutional arrangements for land-sea governance, how governance has typically functioned (or not), and priorities for improving governance into the future. Maps of the study sites at various scales were used to assist in gathering data during interviews, and respondents could interact directly with the maps (e.g., refer to areas of problematic land use).

Table 2. Overview of sample.

\begin{tabular}{lcc}
\hline \hline & Saint Lucia $(n)$ & Dominica $(n)$ \\
\hline Interviews & 55 & 56 \\
Participants & 65 & 60 \\
Actors & 35 & 47 \\
Full information & 28 & 36 \\
Partial information & 7 & 11 \\
State & 17 & 19 \\
Nonstate & 18 & 28 \\
Land-interested & 30 & 33 \\
Sea-interested & 15 & 26 \\
\hline
\end{tabular}

Note: some actors are both land- and sea-interested.

\section{Analyzing social-ecological fit across the land-sea interface}

Network analysis has proven a useful tool to characterize socialecological fit and assess the role of governance networks in helping address issues of fit (Bergsten et al. 2014, Bodin et al. 2014, Guerrero et al. 2015a, Kininmonth et al. 2015). Network analysis allows for an SES to be abstracted as a multilevel network of interacting social actors, interconnected ecological entities or resource units, and the interdependencies (e.g., ecosystem services, management authority) between social actors and ecological entities (Bodin and Tengö 2012). Social-ecological fit is analyzed by determining the tendency for certain network building blocks to be present or dominant in producing the observed network (Bodin et al. 2014, Guerrero et al. 2015b, Kininmonth et al. 2015). These building blocks represent various social-ecological network processes and have a theoretically informed and empirically examined relationship with socialecological fit (Bodin et al. 2014), or the ability to address various governance challenges (Guerrero et al. 2015b).

We chose several building blocks to examine social-ecological fit across the land-sea interface (Fig. 2). This approach follows Guerrero et al. (2015a) and Bodin et al. (2016a) and builds off a suite of previous studies (e.g., Bodin et al. 2014, Kininmonth et al. 2015). We used building blocks related to the ability to address the governance challenges underpinning social-ecological misfit in land-sea systems. They capture the capacity of governance to (1) engage knowledge from diverse actors, (2) coordinate the management of shared ecological entities, and (3) account for the biogeochemical (e.g., sedimentation, nutrient flows) and ecological (e.g., species movements) interactions between ecological entities. However, it is important to note that many of the governance capacities captured in the building blocks are hypothesized and their assumptions not fully tested (Bodin et al. $2016 a$ ), which is why our analysis also draws on the qualitative interview data to better interpret the meaning of the building blocks. We know from previous studies that the social-ecological network building blocks are important, but their importance must be confirmed or tested in other contexts. As such, we also contribute to an emerging conversation regarding the role of the building blocks in improving the capacity of self-organizing governance networks of different types to address specific challenges.

Qualitative interview data were transcribed and analyzed in NVivo 10.0 software using a hybrid inductive/deductive approach to qualitative content analysis (Miles and Huberman 1994, Saldana 2010). Broad thematic categories were determined deductively due to the themes of interest (e.g., drivers, institutions, context, success, fit). Subthemes were determined inductively and emerged from the interview data.

\section{Constructing social-ecological networks}

Social-ecological networks - comprised of interacting governance actors and predominant landscape/seascape features - provide a starting point for our analysis of social-ecological fit (Guerrero et al. 2015a, Bodin et al. 2016a). We constructed social-ecological networks for each case study following Bodin and Tengö's (2012) three step approach. Firstly, we defined the relevant socialecological interdependencies. These consisted of management interactions as defined by existing rules (e.g., management authority) or interests (e.g., livelihood dependence) in the respective ecological components. These types of interactions were chosen to capture the ability to influence ecological nodes through management or resource extraction and use. Secondly, we defined our relevant social actors and ecological nodes. Social 
Fig. 2. Network building blocks used to analyze socialecological fit.

\begin{tabular}{|c|c|c|}
\hline Description & Building block & Code \\
\hline \multicolumn{3}{|l|}{ General governance network processes } \\
\hline $\begin{array}{l}\text { Triadic closure - the tendency for collaborators } \\
\text { of collaborators to become collaborators }\end{array}$ & & $\mathrm{Cl}$ \\
\hline $\begin{array}{l}\text { Alternating triadic closure - the tendency for } \\
\text { overlapping triads to form }\end{array}$ & & $\mathrm{C} 2$ \\
\hline $\begin{array}{l}\text { Popularity - the tendency for certain actors to be } \\
\text { more prolific collaborators than others }\end{array}$ & & $\mathrm{C} 3$ \\
\hline \multicolumn{3}{|l|}{ General social-ecological network processes } \\
\hline $\begin{array}{l}\text { Cross-level activity - the tendency for actors } \\
\text { with ties to ecological nodes to also be connected } \\
\text { in the governance network }\end{array}$ & & $\mathrm{C} 4$ \\
\hline $\begin{array}{l}\text { Alternating cross-level activity - the tendency } \\
\text { for actors with many connections to ecological } \\
\text { nodes to have connections in the governance } \\
\text { network }\end{array}$ & & $\mathrm{C} 5$ \\
\hline \multicolumn{3}{|l|}{ Governance challenge 1: Engaging diverse actors } \\
\hline $\begin{array}{l}\text { Collaboration between state (e.g., government } \\
\text { agencies) and nonstate (e.g., fishers' } \\
\text { cooperatives) actors to draw on their distinct } \\
\text { forms of knowledge (Guerrero et al. 2015b, } \\
\text { Bodin et al. 2016b) }\end{array}$ & & MA1 \\
\hline $\begin{array}{l}\text { Collaboration between actors with knowledge of, } \\
\text { and interests in, the terrestrial and coastal-marine } \\
\text { ecosystems to draw on their distinct forms of } \\
\text { knowledge (Álvarez-Romero et al. 2015) }\end{array}$ & & MA2 \\
\hline
\end{tabular}

\begin{tabular}{|c|c|c|}
\hline Description (continued) & Building block & Code \\
\hline \multicolumn{3}{|c|}{ Governance challenge 2: Coordinating management of ecological resources } \\
\hline \multirow{2}{*}{$\begin{array}{l}\text { Collaboration and coordination between actors } \\
\text { with management authority or interests in a } \\
\text { shared ecological entity increases capacities to } \\
\text { sustainably manage that entity (Bodin et al. } \\
\text { 2014, 2016a, Guerrero et al. 2015b, Kininmonth } \\
\text { et al. 2015). Both the simple (CM1) and } \\
\text { alternating form (CM2) are used (Wang et al. } \\
\text { 2016). }\end{array}$} & & CM1 \\
\hline & & CM2 \\
\hline \multicolumn{3}{|c|}{ Governance challenge 3: Ability to address biogeochemical and ecological interactions } \\
\hline \multirow{2}{*}{$\begin{array}{l}\text { Collaboration and coordination between actors } \\
\text { who have management authority or interests in } \\
\text { interconnected ecological entities increases } \\
\text { capacities to sustainably manage these entities } \\
\text { (Bodin et al. 2014, 2016a, Guerrero et al. 2015b, } \\
\text { Kininmonth et al. 2015). Both the simple (BI1) } \\
\text { and alternating form (BI2) are used (Wang et al. } \\
\text { 2016). }\end{array}$} & & BI1 \\
\hline & & BI2 \\
\hline $\begin{array}{l}\text { Collaboration and coordination between actors } \\
\text { who have management authority or interests in } \\
\text { interconnected ecological entities across the } \\
\text { land-sea interface increases capacities to } \\
\text { sustainably manage these entities. Both the } \\
\text { simple and alternating form are potentially } \\
\text { beneficial. }\end{array}$ & & BI3 \\
\hline
\end{tabular}

actors were defined as key organizations and groups involved with some aspect of land-sea governance. The scope included formalized organizations (e.g., government agencies, fisheries cooperatives) and informal, yet organized groups (e.g., unincorporated groups of fishers or farmers). Ecological nodes were defined as key types of habitat, land cover, and land use that are found in each respective landscape and seascape. Thirdly, social-social and ecological-ecological linkages were defined. Presence of collaboration and coordination were used to define social-social linkages since these two forms of interaction are particularly important for network governance (Ansell and Gash 2008). Ecological-ecological links were defined as the potential for either species movements or biogeochemical flows between nodes to capture key land-sea processes (Álvarez-Romero et al. 2011).

Interviews formed the basis for determining whether socialecological, social-social, and ecological-ecological links were present or absent (see Appendix 1). As noted earlier, interview participants were involved with various governance organizations. Representatives from government agencies and livelihood-based cooperatives or community-based organizations were asked to describe how various features of their land-seascapes interacted via multiple processes (e.g., hydrological, species movements, sediment transport). Printed maps containing land cover information and location of important, known seascape features (e.g., coral reefs, seagrass beds) were used to aid the data collection. The ecological networks were triangulated with peerreviewed publications and grey literature - when available - to further improve the validity of our ecological networks (e.g., Nagelkerken 2009). Our approach has limitations since it is not based on monitored or modeled ecological and biogeochemical connections between ecological nodes; however, a strength of our approach is that it engages with, and synthesizes, multiple forms of knowledge - both academic and nonacademic - regarding land-sea processes in our case studies. Similar approaches have been used elsewhere to answer a range of research questions in data-poor contexts (e.g., Vanwindekens et al. 2013, Daw et al. 2015, Walters and Chinowsky 2016). Additionally, our approach is aligned with similar methods in ecology that draw on expert elicitation (Donlan et al. 2010, Martin et al. 2012, McBride et al. 2012).

Our definition of ecological nodes is not identical to that used in similar studies (e.g., Guerrero et al. 2015a, Kininmonth et al. 2015). We defined ecological nodes to reflect the diversity of key landscape and seascape features rather than as the specific features themselves. For example, we chose seagrass in general to be an ecological node that was meant to capture all patches of seagrass found within our study areas, but the nodes were not defined as each patch of seagrass separately. We found our approach particularly useful to abstract the focal SESs in a manner relevant for understanding social-ecological fit across the land-sea interface. It is not the connections between features that are of interest to us but rather the connections between types of features and how these can be governed effectively. Similar approaches have been used elsewhere (see Roldán et al. 2015).

\section{Multilevel exponential random graph models}

We used multilevel exponential random graph models (MERGM) to examine social-ecological fit across the land-sea interface in our case studies. Multilevel networks consist of multiple sets of 
Table 3. Multilevel exponential random graph model estimates.

\begin{tabular}{|c|c|c|c|c|}
\hline \multirow[t]{2}{*}{ Building block } & \multicolumn{2}{|c|}{ Saint Lucia } & \multicolumn{2}{|c|}{ Dominica } \\
\hline & $\begin{array}{c}\text { Estimate } \\
\text { (Standard error) } \\
\end{array}$ & $\begin{array}{c}\text { Observed } \\
(t \text { stat })\end{array}$ & $\begin{array}{c}\text { Estimate } \\
\text { (Standard error) }\end{array}$ & $\begin{array}{c}\text { Observed } \\
(t \text { stat })\end{array}$ \\
\hline $\mathrm{C} 1$ & $0.6524(0.079)^{*}$ & $90(0.075)$ & $0.36(0.049)^{*}$ & $205(-0.054)$ \\
\hline $\mathrm{C} 2$ & $0.4314(0.201)^{*}$ & $127(0)$ & $1.1263(0.223)^{*}$ & $245(-0.029)$ \\
\hline $\mathrm{C} 3$ & $-0.4735(0.39)$ & $251(0.014)$ & $-0.3153(0.273)$ & $449(-0.055)$ \\
\hline $\mathrm{C} 4$ & $-0.6253(0.238)^{*}$ & $508(-0.042)$ & $-0.4773(0.151)^{*}$ & $811(0.086)$ \\
\hline C5 & $0.2068(0.142)$ & $498(-0.026)$ & $0.0975(0.073)$ & $760(0.085)$ \\
\hline MA1 & $-0.6676(0.173)^{*}$ & $29(0.071)$ & $-0.1138(0.174)$ & $66(-0.066)$ \\
\hline MA2 (land) & $-0.1401(0.215)$ & $16(0.089)$ & $-0.0369(0.172)$ & $41(0.09)$ \\
\hline MA2 (sea) & $-0.2458(0.267)$ & $38(-0.071)$ & $-0.3921(0.189)^{*}$ & $42(-0.095)$ \\
\hline CM1 & $0.2684(0.29)$ & $88(-0.012)$ & $0.4451(0.179)^{*}$ & $200(0.082)$ \\
\hline CM2 & $0.6464(0.469)$ & $60(0)$ & $0.1641(0.311)$ & $128(0.08)$ \\
\hline $\mathrm{BI} 1$ & $0.0823(0.07)$ & $450(-0.047)$ & $0.0627(0.047)$ & $756(0.081)$ \\
\hline $\mathrm{BI} 2$ & $0.649(0.213)^{*}$ & $667(-0.045)$ & $0.5068(0.158)^{*}$ & $804(-0.001)$ \\
\hline
\end{tabular}

* significant effect

actors, interactions among actors in each set, and interactions between the actors across each set (Lazega and Snijders 2016). MERGMs are an approach to modeling multilevel networks that acknowledges the interdependence of network ties both within and across levels (Wang et al. 2013). MERGMs treat the empirical or observed networks as dependent variables, and test how various network building blocks can explain the observed network (Lusher et al. 2013a). The starting point for the MERGM analysis is the assumption that network ties are random variables (Robins et al. 2007a). Based on assumptions of stochasticity, the prevalence of observed building blocks is compared to their prevalence in a distribution of randomly generated networks. Regression techniques are used to consider simultaneously the effects of multiple, potentially nested building blocks (Lusher et al. 2013a, Wang et al. 2016).

Multilevel networks and MERGMs have recently been extended to construct and model social-ecological networks (Bodin and Tengö 2012, Bodin et al. 2014, 2016a, Guerrero et al. 2015a, Kininmonth et al. 2015). Multilevel social-ecological networks are constructed following Bodin and Tengö 2012, where the social network consists of one level, the ecological network another level, and the social-ecological interactions are considered the cross-level linkages (Guerrero et al. 2015a). These socialecological networks can then be analyzed using MERGMs to examine the propensity of multiple social-ecological building blocks for producing the observed network.

The building blocks embodying social-ecological fit were focal parameters in our models (Fig. 2). Additionally, we included several control parameters related to general social-ecological network processes. These control parameters include processes related to popularity and closure in the governance network, and the alignment of actor roles in relation to cross-level interactions (i.e., their management interactions). Our approach allows us to account for the effects of the control parameters in our estimates for the building blocks related to social-ecological fit. The building blocks representing social-ecological fit were deemed to be significant if their estimates were twice the standard error (Lusher et al. 2013a). We kept both the ecological network and the interactions between social and ecological networks fixed in the models since we were more concerned about how governance actors organize their social interactions in relation to these other levels and interactions. We fixed the densities of the governance networks ( 0.156 for Saint Lucia; 0.140 for Dominica) to compare the social-ecological fit contributions of our observed networks to random networks with the same densities, which provides a more accurate characterization of these contributions and aids in model convergence. Our models had $t$ scores less than 0.1 for all included parameters and $t$ scores less than 2.0 for other important network characteristics, which suggests a good fit between the observed and modeled networks (Lusher et al. 2013a). We acknowledge that the inclusion of different building blocks may improve the fit of our models; however, we included only specific building blocks related to our interests in socialecological fit and controlled for certain interactions (e.g., management authority) - an approach that is consistent with similar studies (Bodin et al. 2016b). In some cases, we included both basic (i.e., Markov) and alternating parameters in the same model to allow us to distinguish between when the building blocks are distributed versus overlapping (Robins et al. 2007b). We used the software MPNet for our analysis (Wang et al. 2014). The MPNet codes for the different building blocks are provided in Appendix 2.

\section{RESULTS}

\section{General network governance and social-ecological network processes}

It is important to control for general network processes - such as triadic closure and popularity-in the MERGMs to provide a more accurate interpretation of the influence of building blocks related specifically to social-ecological fit. However, these processes also provide insights into the general extent and network drivers of collaboration in the respective cases. The analyses of both case studies suggest considerable collaboration occurs (Table 3 ); however, much of the collaboration is not organized in a way that enhances capacity to address the challenges of social- 
ecological fit examined in this study. Essentially, existing collaboration in the governance networks provides a certain level of capacity to address the focal fit challenges; however, governance actors are not necessarily organized to address these challenges specifically. Regardless, there are important instances where governance networks are enhancing social-ecological fit.

In terms of general network governance processes, triadic closure - or the tendency for collaborators of collaborators to become collaborators - was significant and positive in both cases (Table $3, \mathrm{C} 1$ and $\mathrm{C} 2$ ). However, the greater magnitude of $\mathrm{C} 2$ in the case from Dominica suggests the potential formation of a core group of governance actors, or at least more so than is apparent in the Saint Lucian case. The popularity building block is insignificant in the Dominican case, which suggests that certain actors are not forming more ties to a disproportionate degree (i.e., there are no elite individual actors emerging). The popularity building block is also not present in the Saint Lucian case.

We also controlled for several general social-ecological network processes, specifically the impact that having interests or management authority in the ecological network had on the governance networks formed. Essentially, these processes account for the tendency of actors with more interests or management authority to become relatively more popular in the governance network either because they seek more ties or others seek ties with them ( $\mathrm{C} 4$ and $\mathrm{C} 5$ ). Interestingly, the effect of connections between actors and ecological nodes on the likelihood of tie formation in the governance network was significant and negative in both cases - meaning ties were less likely to form than expected by chance (Table 3). Essentially, connections to the ecological network do not make an actor more likely to be connected in the governance network (C4). Additionally, the building block accounting for actors connected to multiple ecological nodes did not explain tie formation in either case (C5).

\section{Engaging diverse actors}

The governance networks in both contexts contain a wide range of different actors extending beyond the state. For example, the governance network in Dominica includes fishers' cooperatives and community-based groups (e.g., Newtown Fisheries Cooperative), private dive shops (e.g., AnchDive) and divers' associations (e.g., Dominica Watersports Association), and other environmental nongovernmental organizations (e.g., Dominica's Sea Turtle Conservation Organization Inc.). The governance network in Saint Lucia contains a similar mix of actors; however, there is a greater presence of farmers' organizations (e.g., Troumasse Fair Trade Organization) and less presence of the diving industry, which reflects the socioeconomic differences between the case studies. Nonstate actors in both cases are organized both at the community- and national-levels, which means there are community-based organizations or individual businesses that then come together to form national-level umbrella organizations (e.g., National Fair Trade Organization in Saint Lucia) or associations (e.g., Dominica Watersports Association in Dominica). Actors typically maintain autonomy at both levels, which means that community-based actors are free to operate independently of their national-level counterparts, and vice versa. The Saint Lucia network also contains a collaborative partnership at the watershed-level-the Trust for the Management of Rivers (TMR), which was established as part of the regionally focused Integrated Watershed and Coastal Areas Management (IWCAM) project. The TMR is an experiment with participatory watershed management in the Lesser Antilles, and the organization has been able to persist and stay active beyond the time frame of the IWCAM project. It provides a collaborative platform for integrating land-sea management by engaging with, or having representation from, actors with interests or management authority on both sides of the land-sea interface.

Despite the presence of diverse actors in the governance network, collaboration between state and nonstate actors is significantly underrepresented in the Saint Lucian case based on the MERGM results (Table 3; MA1 is significant and negative). The Dominican case shows greater participation of state and nonstate actors; however, MA1 is still not significant in the Dominican case. Participatory governance, as represented by state and nonstate collaboration and coordination, is an ongoing challenge in the Caribbean in general (Scobie 2016), and these challenges are replicated in both case studies. However, Dominica is typically perceived as having a slightly more participatory system than other Small Island Developing States in the Caribbean, which is supported by the following interview quotes.

\begin{abstract}
Dominica has, based on our interactions with the islands, probably one of the strongest community engagement frameworks. We have had activities in Dominica where we've had very strong community involvement and community participation. \#53, Dominica
\end{abstract}

In terms of the governance process, generally we have a top-down governance system. So, the [state agency] assesses the requirements [following] the government's protocol, which establishes the rules and regulations, and asks the communities to comply with those principles and protocols. We [state agency] are seeing that as not very effective, and we [state agency] are trying to change protocols to get stakeholders more involved in the governance activities. \#52, Dominica

The MERGM results do not show any significant network processes related to collaboration between land- and sea-focused actors in Saint Lucia (Table 3; MA2 not significant). In Dominica, collaboration between land- and sea-focused actors is significantly underrepresented (Table 3, MA2 negative). These results suggest that the governance networks do not significantly exhibit land-sea collaboration, although the situation is somewhat better in Saint Lucia than in Dominica. There are examples of land-sea collaboration in both cases, but not enough to suggest the governance networks are geared for land-sea collaboration. Actors are not focusing their collaborative efforts across the land-sea interface, which potentially reduces capacity to address land-sea interactions. Respondents from Saint Lucia demonstrate how collaboration exists, but is still probably insufficient - a view held by most respondents.

So, you would not only have [at meetings] the marinebased organizations, but also the ones that are responsible for the land aspect. Because what we've recognized is a lot of the impacts on the marine environment result from land-based sources. \#41, Saint Lucia

[Governance effectiveness] comes under question sometimes, but I mean, in terms of being inclusive and 
that sort of thing there is at least some capacity there, right? But when it comes to dealing with some of the landbased stuff there's kind of this disconnect between what's happening on land and what's happening in the ocean. \#54, Saint Lucia

\section{Coordinated management of ecological entities}

The coordinated management of ecological entities was recognized as extremely important in both case studies, so much so that this importance has even been captured in a common saying in Saint Lucia:

It's again a dual purpose. There is a Kwéyòl saying. Saying it in English never sounds right. It means that when you have a cow and there are various owners, sometimes that cow can die by the end of the day. Because I am expecting you to check it out, and you are expecting my brother to check it out, and nobody does and the cow dies. Sometimes they say, 'A cow with more than one owner can die at the rope'. \#53, Saint Lucia

This saying was brought up in the context of a discussion around mangrove management in Saint Lucia, and it reflects how mangroves fall under the jurisdiction of multiple state agencies (e.g., Fisheries Department, Forestry Department), and there are multiple groups with interests in mangroves (e.g., fishers, farmers, beekeepers, tour guides). Yet, despite the multiple responsibilities and interests, mangroves have historically been at risk of being destroyed in Saint Lucia (FAO 2005), and limited coordination has been flagged as an underlying issue (Government of Saint Lucia 2009).

The recognized importance of coordinated management in Saint Lucia, yet the potential limits on network-based capacity to achieve it, are also supported by the MERGM results (Table 3). Both CM1 and CM2 are both not significant, which potentially limits governance network capacity for coordinated management. The transaction costs associated with coordinated management were brought up by two respondents as potential barriers:

\begin{abstract}
The main costs that are now an obstacle is in a sense, they're personnel-it's human resources. Because integration is largely facilitation, and it's not much hardware-it's not infrastructure, it's not doing new things; it's doing things differently in a coordinated way. So, it's largely people and their ability to convene and to bring people together, so that's the most important. An integrated approach is not costly, except that it is costly when you have a government that doesn't have resources. \#1, Saint Lucia
\end{abstract}

Now us [state agency] being so caught up in our work, what it normally does, is it restricts our influence and our interaction into the whole aspect of land based planning. \#30, Saint Lucia

Dominica demonstrates an alternative model for coordinated management, where self-organized coordination outside of, but facilitated by, the state has played a considerable role in addition to government-led coordination. The MERGM results suggest that the governance networks in Dominica are geared toward coordinated management to a significant degree (Table 3; CM1 significant and positive). These results capture the coordination of government agencies among themselves but also the coordination of nonstate actors. For example, there is a high degree of coordination within the diving industry that is focused on coastal-marine resource (e.g., coral reefs, seagrass) sustainability. It is common for dive shops to collectively address various problems (e.g., lionfish invasion, marine litter). The Dominica Watersports Association provides the formal, collaborative platform for addressing shared risks, although certain dive shops will also collaborate directly, if the need arises. Additionally, the Local Area Management Authority (LAMA) for the Soufriere-Scott's Head Marine Reserve provides a multisectoral platform for coordination of community-based actors. As part of LAMA, the Dominica Watersports Association and various dive shops can also coordinate with other organizations, such as the Saint Mark's Fisherfolk and Tourism Cooperative, on issues related to coastal-marine and terrestrial sustainability. These networked arrangements have provided significant capacity for coordinated management in Dominica, and their self-organized nature contrasts slightly with the approach in Saint Lucia.

\section{Biogeochemical and ecological interactions}

Coordinated management of shared resources is important. Yet in the context of land-sea interactions, an additional challenge is governing at scales that are able to encompass biogeochemical and ecological interactions among resource units. This challenge usually requires extending governance networks beyond coordinated management of shared resources to coordinated management of interconnected resources (Bodin et al. 2014). The MERGM results suggest that both case studies exhibit capacity to address biogeochemical and ecological interactions between resource units. The BI2 building block is significant and positive in both case studies, which suggests that governance networks are strategically forming in relation to biogeochemical and ecological interactions. However, when taken in conjunction with the lack of significant land-sea collaboration (MA2) and interview results, the MERGM results suggest that this capacity is likely focused more on addressing interactions within terrestrial and marine systems as opposed to between them.

There are examples where actors have intentionally pursued collaboration across the land-sea interface to deal with biogeochemical and ecological interactions. In Dominica, a local dive shop has formed a partnership with a local quarry operator to monitor the health and status of the marine environment in areas potentially impacted by the quarry operator's activities. The development of this arrangement was completely self-organized and not based on any form of intervention from higher levels. The partnership was struck when the local dive shop owner became concerned about possible impacts from the quarry. The two actors met and developed a formal partnership, where the quarry funds the divers to participate in reef check monitoring in potentially sensitive coastal-marine areas. Additionally, the quarry operator has implemented several practices (e.g., settling ponds) to reduce potentially damaging sedimentation and runoff. The success of this initiative has been noted by other dive shops, which have endeavored to create similar partnerships with other quarry operators. However, additional partnerships have yet to take root because they are faced with multiple challenges (e.g., lack of political salience). Despite the challenges, these findings suggest 
that self-organized approaches to land-sea integration can emerge; they just take time to scale-out from their original point of conception.

The interviews also suggest the importance of institutional context, in addition to network governance, for dealing with negative biogeochemical interactions across the land-sea interface in the case study sites. Interview participants in both case studies highlighted the role of hierarchical, nested institutional arrangements-from international to community levels - in reducing agricultural impacts on coastal environments. These arrangements influence the export-oriented, commercial agricultural sectors, which are focused mostly on bananas in both cases and, additionally, citrus in Dominica. Both case study islands relied heavily on agricultural exports and suffered significant hardships following changes in international trade policies during the 1990s, which limited their abilities to access export markets. The fair-trade system was put in place, and quickly took hold in the Lesser Antilles to provide comparative advantage and maintain market connections, especially with the United Kingdom (UK). The fair-trade certification comes with multiple prescriptions for sustainable agricultural practices, many of which reduce the potentially negative impacts of farming on coastal environments (e.g., reduced use of agrochemicals, maintenance of buffer zones). Adherence to these prescriptions is carefully monitored and enforced by authorities, and failure to adhere comes with significant penalty.

Since we are under the fair-trade logo, we have to sell fruits that use as little chemicals as possible. Every year, the guys from the market, they come down, and select five of farmers randomly. We have no idea who they will choose. So, if he is not prepared, everybody has to help that farmer, because if that farmer fails, he is not going to sell [bananas] again. \#34, Saint Lucia

The farmer's farm must be at least 10 feet away from rivers or the beach. He must have a buffer zone, and on the farm, he must have a chemical disposal pit. \#34, Saint Lucia

From the point of view of agriculture itself, we are very concerned about the environment for obvious reasons, but more so, there's been a lot of external pressures, which have been introduced by way of standards in production - which in themselves lead to safeguarding the environment. But I think by far and large as a country, our farmers and our people have been very conscious of the impact of things like pesticides and so on, and have resisted them to a large extent. \#4, Dominica

Although reducing the potential for negative biogeochemical interactions between terrestrial and marine environments, the fair-trade policies and standards are still enforced largely from the outside, and to some degree, they disempower farmers and can create hardships. Most farmers interviewed expressed feeling disempowered by the fair-trade system.

I believe that the farmers are frustrated. They are not making money and all the time there are different rules over them. [For example] they will say, 'Look, we don't want that, we want this,' and the suspension! When you're suspended for things that are out of your control, beyond your control, you are suspended and then you have to sell a product where you make no money. I have been selling bananas, and at times when you recognize that for a suspended farmer, the money that they spend to grow the bananas, they don't get it back. It's very awful! \#18, Saint Lucia

\section{DISCUSSION}

We examined how network governance influences socialecological fit in two case studies of land-sea systems: the southwest coast of Dominica and the southeast coast of Saint Lucia. Both cases exhibit considerable collaboration; however, in some cases, this collaboration was not necessarily organized in a way to specifically tackle issues of social-ecological fit across the land-sea interface. We found that network governance could help engage diverse actors, but existing networks are constrained by the general lack of reliance on participatory governance that is apparent across the Caribbean region (Scobie 2016). The situation is somewhat better in Dominica where there has been a concerted effort to improve participation and erode the barriers imposed by top-down hierarchal governance. However, neither case study exhibits a clear shift in their respective governance networks toward participation and the ability to engage diverse actors and knowledge when making decisions regarding land-sea systems.

Network governance also contributed to the coordinated management of shared resources in both case studies. However, this contribution was much clearer in Dominica, where both state and nonstate actors have self-organized to coordinate management. In Saint Lucia, much of the burden for coordination has been placed on the state, which presents numerous challenges (e.g., lack of funding) for making a clear shift in the governance networks toward coordination. The transaction costs of coordination across the land-sea interface may simply be too high in relation to other priorities for the state. In Dominica, transaction cost issues have been dealt with in a self-organized manner, where nonstate actors have come together autonomously to coordinate their interests in coastal-marine resources. These actors are not as inhibited by budgetary and bureaucratic constraints, and they perceive a direct benefit related to coordinated management (e.g., sustainability of the resources they rely on for their livelihoods). These findings are in line with commonly held notions that network governance can reduce transaction costs (Klijn and Koppenjan 2012); however, our analysis highlights the importance of autonomous networks outside the state for reducing these costs. Transaction costs may impede the overparticipation of the state in network governance.

Coordinated management of interconnected resources to address biogeochemical and ecological interactions is a greater challenge than coordinated management of shared resources based on experience in the case studies. Capacity exists, in both cases, to address such interactions; however, most capacities are focused on interaction within, as opposed to across, marine and terrestrial systems. Again, Dominica shows some promising examples of self-organized collaboration in the face of land-sea interactions, and experiments with participatory coastal watershed governance in Saint Lucia demonstrate promise as well. These examples support an emerging governance network design proposition regarding the specific role of land-sea collaboration or integration in the face of interconnected land-sea resources (Fig. 
2, BI3). The challenge remains finding ways of scaling out such collaborative examples and fostering their persistence (Fig. 3). Existing nested institutional arrangements help address negative biogeochemical interactions, especially as they relate to the agricultural sector, but they also constrain the emergence of empowered and autonomous local actors that can participate in governance networks for addressing land-sea interactions.

Fig. 3. Proposed building block for network governance across the land-sea interface. Note: vector images of the diver and seagrass are from the Integration \& Application Network (http://ian.umces.edu/), with credits to Dieter Tracey and Tracey Saxby, respectively. The rock is from Pixabay, and the excavator is from Clipart Kid.

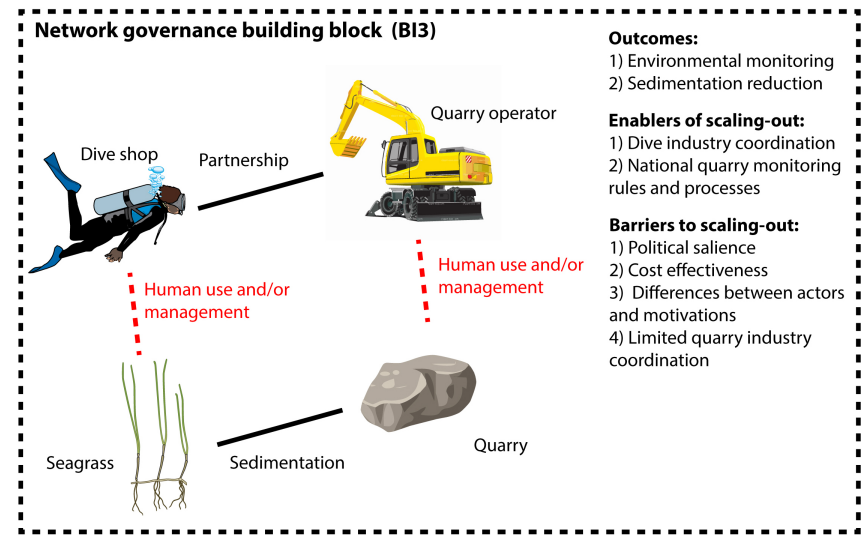

Our research presents two policy implications related to overcoming constraints on network governance for addressing problems in land-sea systems. First, there is the need to balance the interplay between different coexisting modes of governance. Traditionally, top-down forms of governance have been used to address certain land-sea interactions (e.g., agricultural runoff). Although not without their successes, they have served, in some cases, to disempower local resource users and create contexts where local collectives and organizations are not able to participate autonomously in governance networks (Klak et al. 2011), thus paralyzing, in some ways, the emergence of selforganizing network governance. These arrangements also suffer from decreasing legitimacy, as apparent in our interviews as well as in other research (Klak et al. 2011).

Klak et al. (2011) have argued that the current fair-trade rule system fosters negative power relationships, which lead to insecure livelihoods for producers and possible issues with legitimacy and compliance. These issues are also reflected in our observed governance networks (Figs. 3 and 4). Although present in the Saint Lucia case, the local and national fair-trade organizations were not effectively participating in the governance networks. They did not collaborate to a significant degree, especially beyond the agricultural sector. Network governance is possibly constrained in these cases by imposed rules, which have not led to the creation and empowerment of local organizations in the agricultural sector. These rules have definite benefits in reducing negative agricultural impacts on coastal environments (e.g., increased erosion and sedimentation, agrochemical pollution).
Yet, similarly, their benefits are possibly constrained due to their purposive design as an external influence on producers' actions.

Much discussion to date has centered around the agriculture sector in this regard, yet these insights are equally relevant to the current development challenges facing coastal areas across the Caribbean region. The ongoing, and almost uncontrolled, conversion of many near-coast agricultural and forested lands into peri-urban residential areas warrants attention (Walters 2016). Currently, only a select few state agencies are empowered to control such development (e.g., physical planning divisions). Our interviews suggest that these agencies often lack the capacity to monitor and enforce all current developments, and rulesystems are not adequate to prevent attempts at evading the rules, which leads to issues with runoff and sedimentation affecting coastal areas. A potentially more balanced approach to address these issues could involve improved collaboration with local town and constituency councils, which could - with support from state agencies - coordinate other resource users within their jurisdictions to identify development priorities and help monitor their effective implementation.

A second, related insight addresses the potential to leverage existing, network-based capacities to improve network governance. Both cases exhibited limitations in current network structures for fostering collaboration between state and nonstate actors and between land- and sea-focused actors. In both cases, the MERGM results suggested that control variables representing triadic closure, or the propensity for ties to form between collaborators who share a collaborator (Lusher et al. 2013a), were significantly driving the existing, observed network (Table 3). These existing processes could possibly be used to address the identified deficiencies in network structure noted in the Results section by strategically aiming to improve interactions between "collaborators of collaborators," for example, through workshops or other events. The rationale is that triadic closure is an important social process in the existing networks, which could potentially help scale out from any existing collaborations across the landsea interface or between communities and governments. Additionally, the interviews suggest certain capacities for selforganization in Dominica, particularly in the diving sector. The divers' self-organization has been supported by state agenciessometimes through formal partnerships or resource sharing, and other times by not constraining the divers' actions. This approach is perhaps instructive to other stakeholders who represent different sectors or to other islands as a means of fostering more participation-focused governance networks.

Finally, our work highlights two important questions: How much networking is enough to foster social-ecological fit across the land-sea interface? And how does beneficial network governance emerge? Our work suggests that governance networks and networking processes are necessary to enhance social-ecological fit but are not always sufficient. There is still the need to consider - specifically in the context of social-ecological fit-nested institutional arrangements and how different types of interventions constrain or facilitate network development (Klijn and Koppenjan 2012). We have focused on examining network governance in contexts where hierarchies are the dominant mode of governance. More work is required to understand how network governance emerges in such contexts and how networked modes of governance can coexist with other modes. 


\section{CONCLUSIONS}

We examined how different and self-organizing governance networks affect social-ecological fit across the land-sea interface in two case studies from the Lesser Antilles: Saint Lucia and Dominica. Our results suggest that social-ecological fit across the land-sea interface remains somewhat elusive in existing network governance arrangements. Yet there is evidence to suggest that network governance has improved social-ecological fit in both cases. Each case study exhibits different approaches aimed at achieving fit. Network governance has contributed to coordinating management of shared and interconnected resources or ecological entities. However, improved network governance is required to (1) better engage knowledge from diverse actors in decision-making, and (2) address biogeochemical and ecological interactions across, and not just within, marine and terrestrial systems. Strategic use of network processes could help improve social-ecological fit by fostering improved collaborations with diverse groups. Additionally, our research highlights the need to better understand the conditions that foster network governance in support of social-ecological fit across the land-sea interface. More research is required to examine how network governance for social-ecological fit emerges in contexts where hierarchical modes of governance currently dominate.

Responses to this article can be read online at: http://www.ecologyandsociety.org/issues/responses. php/9593

\section{Acknowledgments:}

Support for this project was provided by the Partnership for CanadaCaribbean Community Climate Change Adaptation project funded by Canada's International Development Research Centre (IDRC) and the Social Science and Humanities Research Council (SSHRC). Pittman's research has been further supported with an SSHRC Joseph-Armand Bombardier Canada Graduate Scholarship Doctoral Award and an Ontario Graduate Scholarship award. Armitage's research is further supported by SSHRC through the OceanCanada Partnership and the Community Conservation Research Network. We acknowledge the helpful feedback of three anonymous reviewers, as well as constructive comments by Tony Charles, Bob Gibson, and Scott Slocombe on an earlier draft.

\section{LITERATURE CITED}

Âlvarez-Romero, J. G., V. M. Adams, R. L. Pressey, M. Douglas, A. P. Dale, A. A. Augé, D. Ball, J. Childs, et al. 2015. Integrated cross-realm planning: a decision-makers' perspective. Biological Conservation 191:799-808. https://doi.org/10.1016/j.biocon.2015.07.003

Âlvarez-Romero, J. G., R. L. Pressey, N. C. Ban, K. VanceBorland, C. Willer, C. J. Klein, and S. D. Gaines. 2011. Integrated land-sea conservation planning: the missing links. Annual Review of Ecology, Evolution, and Systematics 42(1):381-409. http://dx. doi.org/10.1146/annurev-ecolsys-102209-144702

Ansell, C., and A. Gash. 2008. Collaborative governance in theory and practice. Journal of Public Administration Research and Theory 18(4):543-571. http://dx.doi.org/10.1093/jopart/mum032
Armitage, D. R., R. Plummer, F. Berkes, R. I. Arthur, A. T. Charles, I. J. Davidson-Hunt, A. P. Diduck, N. C. Doubleday, D. S. Johnson, M. Marschke, P. McConney,E. W. Pinkerton, and E. K. Wollenberg. 2009. Adaptive co-management for socialecological complexity. Frontiers in Ecology and the Environment 7(2):95-102. http://dx.doi.org/10.1890/070089

Bergsten, A., D. Galafassi, and Ö. Bodin. 2014. The problem of spatial fit in socio-ecological systems: detecting mismatches between ecological connectivity and land management in an urban region. Ecology and Society 19(4):6. http://dx.doi. org/10.5751/ES-06931-190406

Bixler, R. P., S. Johnson, K. Emerson, T. Nabatchi, M. Reuling, C. Curtin, M. Romolini, and J. M. Grove. 2016. Networks and landscapes: a framework for setting goals and evaluating performance at the large landscape scale. Frontiers in Ecology and the Environment 14(3):145-153. http://dx.doi.org/10.1002/ fee. 1250

Bodin, Ö., B. Crona, M. Thyresson, A.-L. Golz, and M. Tengö. 2014. Conservation success as a function of good alignment of social and ecological structures and processes. Conservation Biology 28(5):1371-1379. http://dx.doi.org/10.1111/cobi.12306

Bodin, Ö., G. Robins, R. R. J. Mcallister, A. M. Guerrero, B. Crona, M. Tengö, and M. Lubell. 2016a. Theorizing benefits and constraints in collaborative environmental governance: a transdisciplinary social-ecological network approach for empirical investigations. Ecology and Society 21(1):40. http://dx. doi.org/10.5751/ES-08368-210140

Bodin, Ö., A. Sandström, and B. Crona. 2016b. Collaborative networks for effective ecosystem-based management: a set of working hypotheses. Policy Studies Journal 0(0):1-26.

Bodin, Ö., and M. Tengö. 2012. Disentangling intangible socialecological systems. Global Environmental Change 22(2):430-439. http://dx.doi.org/10.1016/j.gloenvcha.2012.01.005

Borrás, S., and H.-P. Olsen. 2007. Combining qualitative and quantitative methods for the analysis of network governance: promises, problems, pay-offs and potentials. Pages 207-223 in P. Bogason and M. Zølner, editors. Methods in democratic network governance. Palgrave Macmillan, London, UK. http://dx.doi. org/10.1057/97802306274689

Daw, T. M., S. Coulthard, W. W. L. Cheung, K. Brown, C. Abunge, D. Galafassi, G. D. Peterson, T. R. McClanahan, J. O. Omukoto, and L. Munyi. 2015. Evaluating taboo trade-offs in ecosystems services and human well-being. Proceedings of the National Academy of Sciences of the United States of America 112:69496954. http://dx.doi.org/10.1073/pnas.1414900112

Donlan, C. J., D. K. Wingfield, L. B. Crowder, and C. Wilcox. 2010. Using expert opinion surveys to rank threats to endangered species: a case study with sea turtles. Conservation Biology 24 (6):1586-1595. http://dx.doi.org/10.1111/j.1523-1739.2010.01541. $\underline{\mathrm{X}}$

Duit, A., and V. Galaz. 2008. Governance and complexityemerging issues for governance theory. Governance: an International Journal of Policy, Administration, and Institution 21 (3):311-355. http://dx.doi.org/10.1111/j.1468-0491.2008.00402. X 
Duit, A., V. Galaz, K. Eckerberg, and J. Ebesson. 2010. Governance, complexity, and resilience. Global Environmental Change 20:363-368. http://dx.doi.org/10.1016/j.gloenvcha.2010.04.006

Ekstrom, J. A., and O. R. Young. 2009. Evaluating functional fit between a set of institutions and an ecosystem. Ecology and Society 14(2):16. http://dx.doi.org/10.5751/ES-02930-140216

Engle, N. L., and M. C. Lemos. 2010. Unpacking governance: building adaptive capacity to climate change of river basins in Brazil. Global Environmental Change 20(1):4-13. http://dx.doi. org/10.1016/j.gloenvcha.2009.07.001

Epstein, G., J. Pittman, S. M. Alexander, S. Berdej, T. Dyck, U. Kreitmair, K. J. Raithwell, S. Villamayor-Tomas, J. Vogt, and D. Armitage. 2015. Institutional fit and the sustainability of socialecological systems. Current Opinion in Environmental Sustainability 14:34 40. http://dx.doi.org/10.1016/j.cosust.2015.03.005

Ernoul, L., and A. Wardell-Johnson. 2013. Governance in integrated coastal zone management: a social networks analysis of cross-scale collaboration. Environmental Conservation 40 (3):231-240. http://dx.doi.org/10.1017/S0376892913000106

Folke, C., L. Pritchard, Jr., F. Berkes, J. Colding, and U. Svedin. 2007. The problem of fit between ecosystems and institutions: ten years later. Ecology and Society 12(1):30. http://dx.doi. org/10.5751/ES-02064-120130

Food and Agriculture Organization of the United Nations (FAO). 2005. Global forest resources assessment 2005: thematic study on mangroves Saint Lucia. Rome, Italy.

Galaz, V., P. Olsson, T. Hahn, C. Folke, and U. Svedin. 2008. The problem of fit among biophysical systems, environmental and resources regimes, and broader governance systems: insights and emerging challenges. Pages 147-182 in O. R. Young, L. King, and $\mathrm{H}$. Schroeder, editors. Institutions and environmental change: principal findings, applications, and research frontiers. MIT Press, Cambridge, Massachusetts, USA. http://dx.doi.org/10.7551/ mitpress/9780262240574.003.0005

Glavovic, B. C., K. Limburg, K.-K. Liu, K.-C. Emeis, H. Thomas, H. Kremer, B. Avril, J. Zhang, M. R. Mulholland, M. Glaser, and D. P. Swaney. 2015. Living on the margin in the Anthropocene: engagement arenas for sustainability research and action at the ocean-land interface. Current Opinion in Environmental Sustainability 14:232-238. http://dx.doi.org/10.1016/j.cosust.2015.06.003

Government of Saint Lucia. 2009. Pointe Sable Environmental Protection Area Management Plan, 2009-2014. Castries, Saint Lucia.

Guerrero, A. M., Ö. Bodin, R. R. J. McAllister, and K. A. Wilson. 2015a. Achieving social-ecological fit through bottom-up collaborative governance: an empirical investigation. Ecology and Society 20(4):41. http://dx.doi.org/10.5751/ES-08035-200441

Guerrero, A. M., R. R. J. Mcallister, and K. A. Wilson. $2015 b$. Achieving cross-scale collaboration for large scale conservation initiatives. Conservation Letters 8(2):107-117. http://dx.doi. org/10.1111/conl.12112

Kininmonth, S., A. Bergsten, and Ö. Bodin. 2015. Closing the collaborative gap: aligning social and ecological connectivity for better management of interconnected wetlands. Ambio 44 (S1):138-148. http://dx.doi.org/10.1007/s13280-014-0605-9
Klak, T., J. Wiley, E. G. Mullaney, S. Peteru, S. Regan, and J.-Y. Merilus. 2011. Inclusive neoliberalism? Perspectives from Eastern Caribbean farmers. Progress in Development Studies 11(1):33-61. http://dx.doi.org/10.1177/146499341001100103

Klijn, E.-H., and J. Koppenjan. 2012. Governance network theory: past, present and future. Policy \& Politics 40(4):587-606. http://dx.doi.org/10.1332/030557312X655431

Lazega, E., and T. A. B. Snijders, editors. 2016. Multilevelnetwork analysis for the social sciences: theory, methods and applications. Springer, New York, New York, USA. http://dx.doi. org/10.1007/978-3-319-24520-1

Lusher, D., J. Koskinen, and G. Robins. 2013a. Exponential random graph models for social networks. Cambridge University Press, New York, New York, USA.

Lusher, D., P. Kremer, and G. Robins. 2013b. Cooperative and competitive structures of trust relations in teams. Small Group Research 45(1).

Martin, T. G., M. A. Burgman, F. Fidler, P. M. Kuhnert, S. LowChoy, M. Mcbride, and K. Mengersen. 2012. Eliciting expert knowledge in conservation science. Conservation Biology 26 (1):29-38. http://dx.doi.org/10.1111/j.1523-1739.2011.01806.x

McBride, M. F., S. T. Garnett, J. K. Szabo, A. H. Burbidge, S. H. M. Butchart, L. Christidis, G. Dutson, H. A. Ford, R. H. Loyn, D. M. Watson, and M. A. Burgman. 2012. Structured elicitation of expert judgments for threatened species assessment: a case study on a continental scale using email. Methods in Ecology and Evolution 3(5):906-920. http://dx.doi.org/10.1111/j.2041-210X.2012.00221. $\underline{x}$

Miles, M., and M. Huberman. 1994. Qualitative data analysis: an expanded sourcebook. Sage Publications, Thousand Oaks, California, USA.

Nagelkerken, I., editor. 2009. Ecological connectivity among tropical coastal ecosystems. Springer, New York, New York, USA. http://dx.doi.org/10.1007/978-90-481-2406-0

Newig, J., D. Günther, and C. Pahl-Wostl. 2010. Synapses in the network: learning in governance networks in the context of environmental management. Ecology and Society 15(4):24. http:// dx.doi.org/10.5751/ES-03713-150424

Norström, A. V., M. Nyström, J. B. Jouffray, C. Folke, N. A. J. Graham, F. Moberg, P. Olsson, and G. J. Williams. 2016. Guiding coral reef futures in the Anthropocene. Frontiers in Ecology and the Environment 14(9):490-498. http://dx.doi.org/10.1002/ fee. 1427

Pittman, J., and D. Armitage. 2016. Governance across the landsea interface: a systematic review. Environmental Science \& Policy 64:9-17. http://dx.doi.org/10.1016/j.envsci.2016.05.022

Pittman, J., D. Armitage, S. Alexander, D. Campbell, and M. Alleyne. 2015. Governance fit for climate change in a Caribbean coastal-marine context. Marine Policy 51:486-498. http://dx.doi. org/10.1016/j.marpol.2014.08.009

Rijke, J., R. Brown, C. Zevenbergen, R. Ashley, M. Farrelly, P. Morison, and S. van Herk. 2012. Fit-for-purpose governance: a framework to make adaptive governance operational. Environmental Science \& Policy 22:73-84. http://dx.doi. org/10.1016/i.envsci.2012.06.010 
Rijke, J., M. Farrelly, R. Brown, and C. Zevenbergen. 2013. Configuring transformative governance to enhance resilient urban water systems. Environmental Science \& Policy 25:62-72. http://dx.doi.org/10.1016/j.envsci.2012.09.012

Robins, G., P. Pattison, Y. Kalish, and D. Lusher. 2007a. An introduction to exponential random graph $\left(\mathrm{p}^{*}\right)$ models for social networks. Social Networks 29(2):173-191. http://dx.doi. org/10.1016/j.socnet.2006.08.002

Robins, G., T. Snijders, P. Wang, M. Handcock, and P. Pattison. $2007 b$. Recent developments in exponential random graph $\left(\mathrm{p}^{*}\right)$ models for social networks. Social Networks 29(2):192-215. http:// dx.doi.org/10.1016/j.socnet.2006.08.003

Roldán, V. A., S. Villasante, and L. Outeiro. 2015. Linking marine and terrestrial ecosystem services through governance social networks analysis in Central Patagonia (Argentina). Ecosystem Services 16:390-402. http://dx.doi.org/10.1016/j.ecoser.2015.02.010

Saffache, P., and P. Angelelli. 2010. Integrated coastal zone management in small islands: a comparative outline of some islands of the Lesser Antilles. Journal of Integrated Coastal Zone Management 10(3):255-279. http://dx.doi.org/10.5894/rgci228

Saldana, J. 2010. The coding manual for qualitative researchers. Sage Publications, Los Angeles, California, USA.

Sandström, A., B. Crona, and Ö. Bodin. 2014. Legitimacy in comanagement: the impact of preexisting structures, social networks and governance strategies. Environmental Policy and Governance 24(1):60-76. http://dx.doi.org/10.1002/eet.1633

Scobie, M. 2016. Policy coherence in climate governance in Caribbean Small Island Developing States. Environmental Science \& Policy 58:16-28. http://dx.doi.org/10.1016/j.envsci.2015.12.008

Sweeney, V., and C. Corbin. 2011. The implications of land-based activities in small islands for marine EBM. Pages 57-68 in L. Fanning, R. Mahon, and P. McConney, editors. Towards marine ecosystem-based management in the wider Caribbean. Amsterdam University Press, Amsterdam, Netherlands.

Vanwindekens, F. M., D. Stilmant, and P. V. Baret. 2013. Development of a broadened cognitive mapping approach for analysing systems of practices in social-ecological systems. Ecological Modelling 250:352-362. http://dx.doi.org/10.1016/j. ecolmodel.2012.11.023

Voß, J.-P., J. Newig, B. Kastens, J. Monstadt, and B. Nölting. 2007. Steering for sustainable development: a typology of problems and strategies with respect to ambivalence, uncertainty and distributed power. Journal of Environmental Policy \& Planning 9 (3-4):193-212. http://dx.doi.org/10.1080/15239080701622881

Walters, B. B. 2016. Migration, land use and forest change in St. Lucia, West Indies. Land Use Policy 51:290-300. http://dx.doi. org/10.1016/j.landusepol.2015.11.025

Walters, J. P., and P. S. Chinowsky. 2016. Planning rural water services in Nicaragua: a systems-based analysis of impact factors using graphical modeling. Environmental Science \& Policy 57:93100. http://dx.doi.org/10.1016/j.envsci.2015.12.006
Wang, P., G. Robbins, P. Pattison, and J. Koskinen. 2014. MPNetprogram for the simulation and estimation of exponential random graph models for multilevel networks. Melbourne, Australia.

Wang, P., G. Robins, and P. Matous. 2016. Multilevel network analysis using ERGM and its extension. Pages 125-139 in E. Lazega and T. Snijders, editors. Multilevel network analysis for the social sciences. Springer, Berlin, Germany. http://dx.doi. org/10.1007/978-3-319-24520-1 6

Wang, P., G. Robins, P. Pattison, and E. Lazega. 2013. Exponential random graph models for multilevel networks. Social Networks 35(1):96-115. http://dx.doi.org/10.1016/j.socnet.2013.01.004

Young, O. 2002. The institutional dimensions of environmental change: fit, interplay and scale. MIT Press, Cambridge, Massachusetts, USA. 
Appendix 1. Construction of social-ecological networks.

The social-ecological networks were constructed using interview data, and ecological networks were triangulated using key references on tropical coastal ecology (e.g., Nagelkerken 2009). The following sections provide additional information on how each type of network tie was determined from the interview data.

\section{Governance ties}

Governance ties were elicited using a name-generator approach with free-recall (Marsden 2011), which means respondents were asked to identify the names of organizations with whom they collaborate or coordinate. We asked separately about collaboration and coordination using the questions below. However, these two sets of network ties were later combined and used as a single set of ties in the analysis, since it was clear that the sets were very similar.

1) Does your organization collaborate on project implementation with other organizations? If so, please list these other organizations.

a. Please describe the nature of collaboration with each organization.

b. Were these endeavours successful? Why/not?

2) Does your organization coordinate its actions with other organizations? If so, please list these other organizations.

a. Please describe the nature coordination with each organization.

b. Were these endeavours successful? Why/not?

\section{Ecological ties/interactions}

Ecological ties/interactions were identified from the interviews and triangulated with secondary sources. The sample of respondents included resource managers from government organizations, NGO staff with expertise in conservation, ecology or social-ecological sustainability, and resource users with intimate knowledge of the environments they depend on for their livelihoods. Respondents were asked a series of questions that walked them through (1) relevant challenges in the coastal-marine space, (2) relevant challenges in watersheds and terrestrial areas, (3) their conception of land-sea interactions or challenges, and (4) the interactions between these challenges. Each set of challenges represents key interactions within and between land- and seascape components, and the respondents were asked follow up questions to clarify these interactions. Additionally, we led with open-ended questions about each type of challenge, which was followed up with probing questions regarding specific challenges of interest.

Our approach allowed for relevant challenges/interactions to emerge based on the respondents' experience and knowledge, but we were also able to gather information on challenges of interest for the research. We stepped through these questions about the different system components (e.g., coastal-marine, watershed/terrestrial) separately to better capture the breadth of relevant 
challenges and interactions. Land-sea interactions is somewhat abstract, so our intent was to ask about them in a more easily and communicable way by first understanding challenges in the land- and seascapes separately. However, we also asked directly about land-sea interactions to get a better sense of how these are framed and/or understood by experts in each context. Maps containing land cover information and the locations of known seascape features (e.g., coral reefs, seagrass beds) were used as boundary objects during the interviews, and they provided respondents the opportunity to clarify the spatial nature/extent of their responses. Respondents could point to or draw on, etc. the maps, which provided additional information that was documented and used to aid in interview interpretation. The main land- and seascape features included in the maps and, subsequently, the networks are found in Table A1.

1) What are the main issues or challenges facing coastal-marine areas?

Probe: sedimentation, agrochemicals, sewage, litter, sea-level arise, coastal erosion

a. What is the most important challenge?

b. Where are these challenges most prevalent? Why? Prop: map

2) What are the main issues or challenges facing watersheds/ terrestrial areas?

Probe: salinization of water supplies, storm surge, soil salinization, landslides/erosion

a. What is the most important challenge?

b. Where are these challenges most prevalent? Why? Prop: map

3) What are the main issues or challenges in relation to land-sea interactions?

a. What is the most important challenge?

b. Where are these challenges most prevalent? Why? Prop: map

4) Are these issues and challenges interrelated? If so, why and how?

\section{Social-ecological ties}

Social-ecological ties were elicited by asking respondents about their formal mandates or roles in relation to land- and seascape governance and management, and the main features on which their livelihoods depend (if relevant). The questions below were used to systematically uncover the different types of authorities, activities and interests in different land-sea system components. As above, this information was first elicited with open-ended questions, which were followed by probing questions on ties of interest to capture both pre-determined and emergent ties of relevance. Once again, maps were used (the same maps as above) to gather spatially-relevant information when it helped clarify or added pertinent information. This information was also documented and used to assist in interview interpretation. 
1) What is the mandate of your organization? Probe: main thematic work areas

2) How does your organization address land-ocean interactions?

3) What types of projects or activities does your organization typically undertake to address landocean interactions? Probe: stream enhancement, riparian area management, agricultural extension, public awareness, planning, monitoring, scientific assessment, sedimentation control, regulation, evaluation.

a. Where have these projects taken place? Prop: map

4) [If resource users association or informal group] Where do the majority of your members derive their livelihoods? Which areas are you most concerned about? Prop: map

Table A1.1. Key landscape and seascape features in the ecological networks.

\begin{tabular}{llll}
\hline Ecological node & Abbreviation & Saint Lucia & Dominica \\
\hline Inland Tropical Forest & ITF & $\mathrm{X}$ & $\mathrm{X}$ \\
Scrub Forest & SF & $\mathrm{X}$ & $\mathrm{X}$ \\
Mangrove & MAN & $\mathrm{X}$ & \\
Nearshore & NS & $\mathrm{X}$ & $\mathrm{X}$ \\
Coral Reef & CR & $\mathrm{X}$ & $\mathrm{X}$ \\
Beach & $\mathrm{B}$ & $\mathrm{X}$ & $\mathrm{X}$ \\
Small Offshore Islands & SOI & $\mathrm{X}$ & $\mathrm{X}$ \\
Seagrass & SG & $\mathrm{X}$ & $\mathrm{X}$ \\
Riparian Areas & RA & $\mathrm{X}$ & $\mathrm{X}$ \\
Surface Water & $\mathrm{R}$ & $\mathrm{X}$ & $\mathrm{X}$ \\
Offshore & OS & $\mathrm{X}$ & \\
Grassland & GL & $\mathrm{X}$ & $\mathrm{X}$ \\
Agricultural Lands & AL & $\mathrm{X}$ & $\mathrm{X}$ \\
Urban/Town & UT & $\mathrm{X}$ & $\mathrm{X}$ \\
Quarries & QL & & \\
\hline
\end{tabular}


Appendix 2. MPNet codes for the building blocks.

\begin{tabular}{|l|l|}
\hline Code & MPNet \\
\hline C1 & TriangleA \\
\hline C2 & ATA \\
\hline C3 & ASA \\
\hline C4 & Star2Ax \\
\hline C5 & StarAX1A \\
\hline MA1 & Mismatch \\
\hline MA2 & Mismatch \\
\hline CM1 & TriangleXAX \\
\hline CM2 & ATXAX \\
\hline BI1 & C4AXB \\
\hline BI2 & AC4AXB \\
\hline
\end{tabular}

